\title{
Population dynamics and reproductive phenology of a harvestman in a tidal freshwater wetland
}

\author{
PATRICIA P. IGLESIAS \& MARTÍN O. PEREYRA
}

\begin{abstract}
There is a great amount of ecological information for terrestrial arthropods in several types of habitats, but few studies have focused on populations living in tidal freshwater wetlands. During a two-year field survey, we studied the temporal dynamics of the harvestman Discocyrtus prospicuus inhabiting a freshwater wetland exposed to predictable tides and unpredictable floods. We also explored the effects of temperature, precipitation, and tide level on the population dynamics and reproductive phenology. Our findings are markedly different from those reported in other harvestman species living in different habitats and also from conspecific populations living in the mainland. Adults, subadults, and juveniles remain active throughout the year, and a long breeding season was observed. However, the number of adults, subadults, juveniles, and egg clutches showed clear variations over the year without a consistent seasonal pattern. Contrary to the general pattern in harvestmen, no climatic variables were significant predictors of abundance fluctuations. We discuss the potential masking effect of unpredictable flood events, obscuring the relationship between abundance and abiotic factors. In addition, given that climatic conditions seem to favor harvestmen activity throughout the year, we also hypothesized that abundance variations could be driven mainly by biotic rather than by abiotic interactions.
\end{abstract}

Key words: Abiotic factors, breeding season, phenology, sex-ratio, unpredictable floods.

\section{INTRODUCTION}

Temperature and precipitation are key factors influencing the spatial and temporal distribution ofterrestrial arthropods(Chown \& Nicolson 2004). These two abiotic factors are also considered the most critical determinants of the distribution, habitat use, and richness of species belonging to the order Opiliones, commonly known as harvestmen or daddy long-legs. Harvestman species are usually absent at the lower ends of temperature and precipitation ranges but are diverse and abundant in places with moderate to high temperature and precipitation (reviewed by Curtis \& Machado 2007). In a study conducted along three elevational gradients in the
Brazilian Atlantic Forest, both species density and specimen abundance of litter-dwelling harvestmen were positively correlated with temperature and humidity (Almeida-Neto et al. 2006). Lack of spiracular control, low osmotic hemolymph concentration, and a high surface/ volume ratio may explain why harvestmen occur mainly in damp and shaded areas (Santos 2007). Temperature and precipitation are also important determinants of harvestmen phenology, influencing embryonic, and postembryonic development, as well as adult activity (Belozerov 2012). A recent comparative study, including more than 100 harvestman species belonging to all living suborders and distributed worldwide, has shown that the length of the 
breeding season is primarily influenced by the number of warm months. Precipitation plays a significant, but secondary role in modulating the period devoted to reproduction (Machado et al. 2016).

The role of other abiotic factors on the ecology and phenology of harvestman species is far less studied. For European trogulids (Dyspnoi), for instance, species occurrence is correlated with soils derived from limestone, which are rich in calcium carbonates (Hillyard \& Sankey 1989). Given that representatives of this family feed exclusively on snails, organisms that require calcium carbonate to build their shells, the distribution of trogulids may actually reflect the distribution of their prey (Curtis \& Machado 2007). In central Amazonia, reproduction and early development of two species of litterdwelling harvestmen (Laniatores) occur on tree trunks while the forest is flooded. After the water recedes, development to adulthood proceeds on the forest floor before the individuals retreat once more up into the trees (Friebe \& Adis 1983). Thus, for species living in places subject to seasonal flooding, habitat use, population dynamics, and reproductive phenology may be adjusted to annual hydrological regimes.

The harvestman Discocyrtus prospicuus (Holmberg 1876) (Laniatores: Gonyleptidae) is found primarily in shady forests of temperate environments in central and northern regions from Argentina and Uruguay (Acosta \& Guerrero 2011). Some populations inhabit a tidal freshwater wetland in Argentina (the Lower Delta region), a region without a dry season and hot summer (Peel et al. 2007). The hydrological regime is mainly affected by lunar tides, but also by unpredictable floods produced by south to southeastern winds (Kandus \& Malvárez 2004). When the tide level is high, the Lower Delta islands are not flooded. However, the soil is drenched, which may have either positive or negative effects on ground-dweller arthropods (e.g. Anderson \& Smith 2000, Antvogel and Bonn 2001, Vannier 1983, Verhoef 1977). To date, there are no field surveys of harvestmen inhabiting tidal freshwater wetlands, and the only information available about the phenology of $D$. prospicuus is limited to a few ad libitum observations of continental populations from Uruguay (Stanley 2011, Toscano-Gadea 2011). Therefore, the species is an exciting study system to investigate how species adjust the timing of life-cycle events when faced with different environmental parameters (e.g. hydrological regime). Here we describe the temporal dynamics of the harvestman $D$. prospicuus inhabiting a Lower Delta island during a twoyear field survey. In addition, we investigate whether variation in temperature, precipitation, and tide level influence the population dynamics and reproductive phenology in this island population.

\section{MATERIALS AND METHODS}

\section{Study area}

We conducted this study in one of the Lower Delta islands of the Paraná River (342 $22^{\prime} 55^{\prime \prime}$, $58^{\circ} 34^{\prime} 38^{\prime \prime} \mathrm{W}$; $\sim 8 \mathrm{~m}$ above sea level) in the northeastern part of the Buenos Aires province, Argentina. This region is a tidal freshwater wetland with a temperate climate: mean annual temperature of $16.7{ }^{\circ} \mathrm{C}\left(\min .-\max .=6-30{ }^{\circ} \mathrm{C}\right)$ and mean annual rainfall of $1,073 \mathrm{~mm}$, without marked monthly variation in precipitation levels (Kandus \& Malvárez 2004; Fig. 1). The island lies in the downstream sector of the Lower Delta region, which is dominated by predictable tides and unpredictable floods produced by south to southeastern winds (Kandus \& Malvárez 2004). Winds can raise the water level up to $2.5 \mathrm{~m}$ above the average level, and floods may last from several hours to a few days (Kandus et 
al. 2006). The flooding period depends, among other things, on the topography because the island has an elongated shape with levees surrounding their perimeter and a depressed central portion that accumulates water (Fig. 2). Because the study island shows a high degree of anthropization, we selected a slightly treecovered area of 2,500 $\mathrm{m}^{2}$ located 40-120 m inland from the stream coast as the sampling area. This site is only occasionally flooded and has moderate draining efficiency (Fig. 2). Moreover, the site has numerous fallen logs that can be used by individuals of $D$. prospicuus as diurnal shelter and/or oviposition sites.

\section{Fieldwork}

As unpredictable floods change the location and number of fallen logs that can be inspected, we were unable to mark and track marked logs to be used as sampling units throughout the entire fieldwork. Thus, the sampling method was based on examining all fallen logs found within the sampling area $\left(2,500 \mathrm{~m}^{2}\right)$. The sampling area was inspected each month from August 2012 to July 2014 , totaling two years of samples. The survey began regularly at 10:00 AM, and it usually lasted from 3 to 3.5 hours, during which we carefully inspected all fallen logs in the sampling area. From each log, we recorded the number and sex of adults and subadults, the number of juveniles, and the number of egg clutches. We visited the study site once a month, and each monthly sampling lasted one day. Given that the harvestmen we found each month were not collected or individually marked, the same individual could be counted in different samplings during the study period.

Adult harvestmen can be easily distinguished from subadults because the later do not have complete tarsal segmentation. Moreover, males and females of $D$. prospicuus can be easily distinguished because males have conspicuous

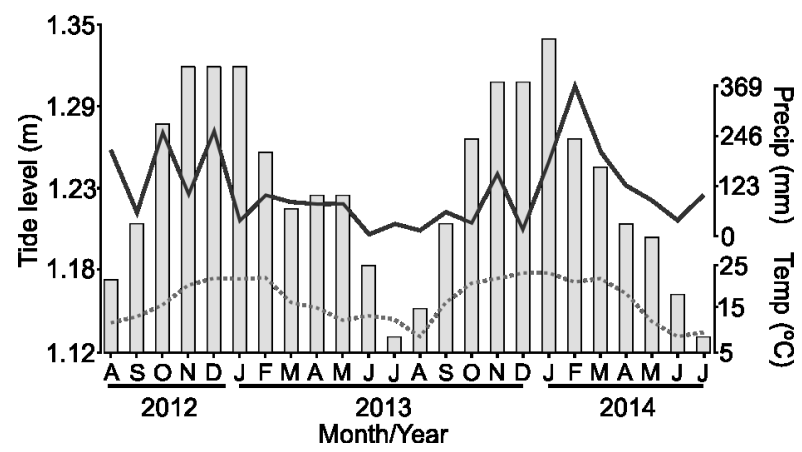

Figure 1. Monthly climatic data recorded during two years of monthly samples in a tidal freshwater wetland from Argentina. Temp: average of the mean daily temperature (dotted line); Precip: cumulative precipitation (solid line); Tide level: average of the daily highest tide (bars).

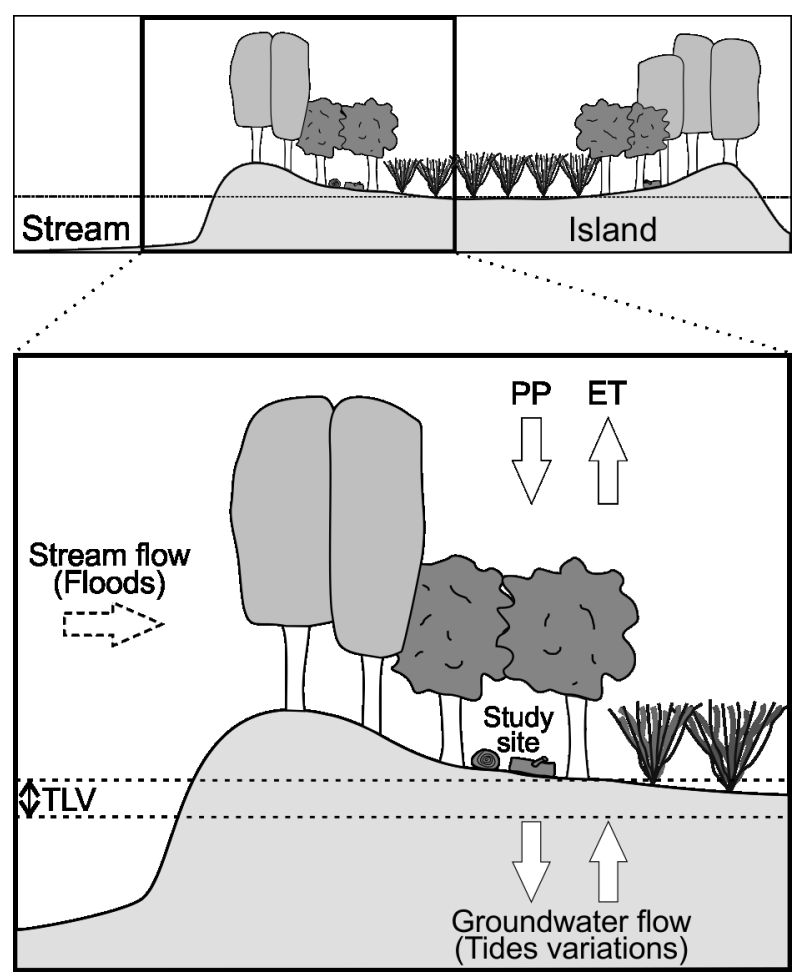

Figure 2. Schematic representation of the island topography showing the study area, the principal water inputs, and tide level variations (TLV). Figure adapted from Kandus \& Malvárez (2004) and Batzer \& Boix (2016). 
spines on the coxa and femur of the fourth pair of legs (Ringuelet 1959). Subadult males can be distinguished from fifth instar juveniles because the former already have incipient armature on the coxa and femur of the fourth pair of legs. Subadult females can be distinguished from fifth instar juveniles by differences in body size. According to measures we took from individuals collected during preliminary surveys, the dorsal scute length of subadult females is always larger than $3.4 \mathrm{~mm}$. Thus, all non-adult individuals without any signal of leg armature and smaller than $3.4 \mathrm{~mm}$ were classified as juveniles. Finally, females of the population studied here do not lay isolated eggs, as previously recorded for $D$. prospicuus populations in the mainland (Canals 1936). Instead, the eggs are laid in small clutches, and females were seen resting over the eggs ( $P$. P. Iglesias and M. O. Pereyra, unpublished data). Therefore, it was easy to locate and record the presence of egg clutches under the fallen logs during the study period.

Voucher specimens were deposited in the Arachnological collection of the Museo Argentino de Ciencias Naturales "Bernardino Rivadavia" - CONICET, Buenos Aires, Argentina (MACN-Ar 40300).

\section{Climatic data}

Temperature and precipitation data were obtained from the Meteorological Station "Delta del Paraná" (Instituto Nacional de Tecnología Agropecuaria, INTA), located $35 \mathrm{~km}$ from the study site. Tide records for San Fernando Port were obtained from Servicio de Hidrografía Naval, Ministerio de Defensa de la República, Argentina. Monthly data are based on average daily temperature, cumulative precipitation, and the average of the daily highest tide (Fig. 1).

\section{Statistical analyses}

To compare the number of males and females (subadults and adults) recorded in the sampling area at each month, we used a generalized linear model (GLM) with a binomial distribution of errors. If mean monthly sex ratio (number males / number of females) estimated by the model was higher than one and the 95\% confidence interval (CI) did not cross one, we considered the sex ratio male-biased. In turn, if the mean monthly sex ratio estimated by the model was lower than one, and the $95 \% \mathrm{Cl}$ did not cross one, we considered the sex ratio female-biased.

To evaluate the effect of temperature, precipitation, and tide level (predictor variables) on the number of adults, subadults, juveniles, and egg clutches (response variables), we used generalized least square (GLS) models. Although the typical analysis for count data is a GLM with Poisson distribution of errors and log link function, our response variables were temporally auto-correlated, and the assumption of independence was not met. Therefore, we chose to pursue a more complex but appropriate model framework. To account for the auto-correlation effect, a temporal correlation structure (auto-regressive model of order 1:AR-1) was included in GLS analyses. The correlation structure considers that the farther away two data points are separated in time, the lower their correlation is (Zuur et al. 2009). We assessed multi-collinearity between the predictor variables by means of variance inflation factors (VIFs) using the vif function from the car package (Fox et al. 2007). The VIFs of each variable were in the range of 1.00 to 1.05 , which indicates low levels of multi-collinearity (following Dormann et al. 2013 and Esposito Vinzi et al. 2010). The predictor variables were fitted as residuals obtained from a linear regression against day length to remove the seasonal trend (Rivrud et al. 2010). They were centered 
and standardized to make the coefficients of the models comparable (Schielzeth 2010). The variables number of clutches, subadults, and juveniles were square-root transformed to meet statistical criteria of normality. The list of candidate models included a complete model containing only the additive effect of the three predictor variables and all combinations of simpler models, including the null model. We choose the most plausible model selecting the one with the lowest AICC, which is the Akaike's information criterion (AIC) for small samples (Bolker 2008, Symonds \& Moussalli 2011). The most parsimonious model was the one with the lowest AICC value, \& all models with $\triangle \mathrm{AICC}<2$ were considered as equally parsimonious (Burnham \& Anderson 2003). Variables were considered important if their model-averaged 95\% confidence intervals did not overlap zero.

All the statistical analyses were run in the software R version 3.5.1 (R Core Team 2015) using the packages nlme (Pinheiro et al. 2014) and MuMIn (Barton 2015).

\section{RESULTS}

\section{Phenology}

Adults of $D$. prospicuus were recorded throughout the year, but we found a decrease in the number of individuals during the austral late spring-early summer period (Fig. 3a). The lowest number of individuals was recorded in December 2013. We recorded juveniles during all months and subadults during all months except August 2012 and November 2013. The number a)

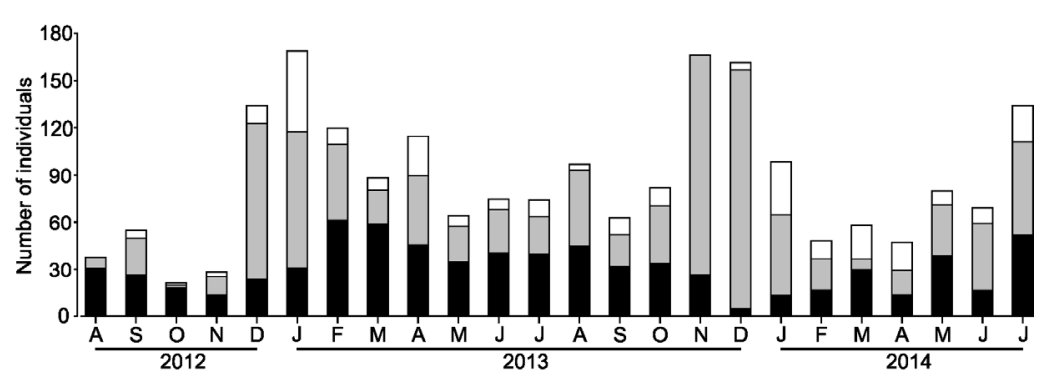

b)

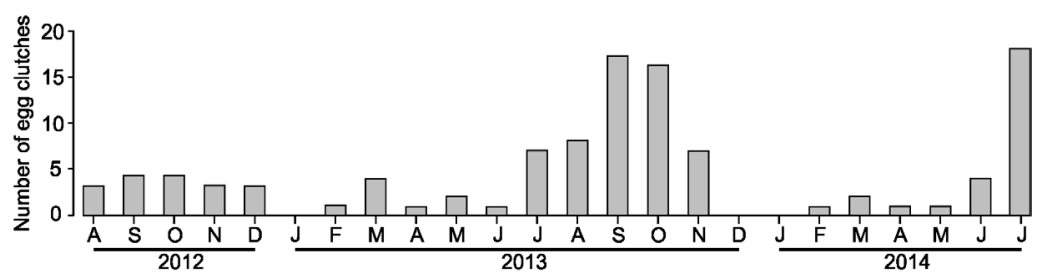

c)

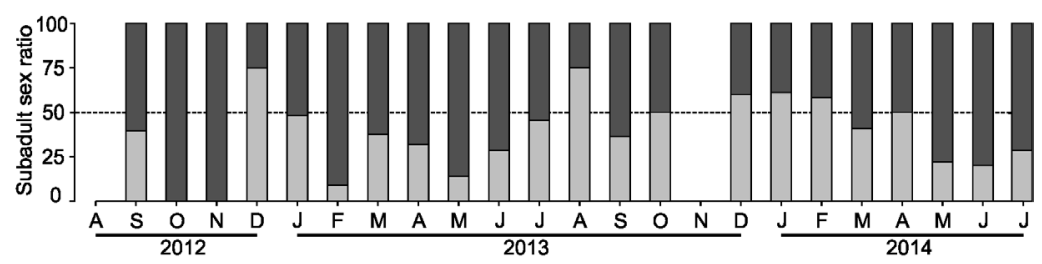

d)

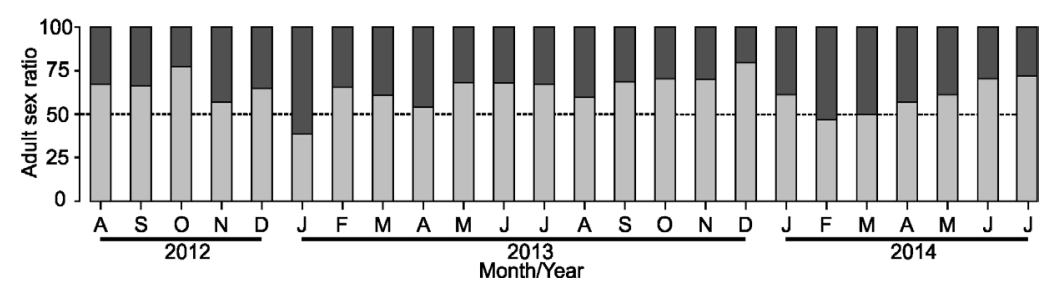

Figure 3. Population dynamics and reproductive phenology of the harvestman Discocyrtus prospicuus in a tidal freshwater wetland from Argentina. (a) Monthly numbers of adults (black), subadults (white), and juveniles (gray). (b) Monthly numbers of egg clutches found in each month. (c) Monthly sex-ratio of subadults (males = dark grey; females = light grey). (d) Monthly sex-ratio of adults (males = dark grey; females = light grey). 
of juveniles showed a peak in December 2012January 2013 and November-December 2013 (Fig. 3a). The number of subadults, in turn, showed a peak in January, both in 2013 and 2014 (Fig. 3a). Egg clutches were found throughout the year, except in January and December 2013, and January 2014 (Fig. 3b). There were peaks in the number of egg clutches in September-October 2013 and July 2014 (Fig. 3b). In general, subadult sex ratio was male-biased (estimate $=1.34$; $95 \% \mathrm{Cl}=1.07-1.69$, Fig. 3c). However, adult sex ratio was female-biased (estimate $=0.57 ; 95 \%$ $\mathrm{Cl}=0.49-0.66$, Fig. $3 \mathrm{~d}$ ). From the 24 months of samplings, in only two we found more adult males than adult females (Fig. 3d).

\section{Effects of abiotic factors}

The environmental variables included in this study had little effect on monthly variations in population composition (Table I). The bestranked model to describe monthly variations in the number of adults included temperature, precipitation, and tide level (Table I). In contrast, the null model was the best ranked model to describe monthly variations in the abundance of subadults, juveniles, and egg clutches (Table I). Although one or more predictor variables were included in the other models with $\triangle \mathrm{AICC}<2$ for the four response variables (Table I), no predictor variables were considered important when coefficients were model-averaged, with all 95\% confidence intervals overlapping zero (Table II).

\section{DISCUSSION}

Seasonal variations in population size seem to be the rule among harvestmen, and this pattern has already been described for several species living in both temperate and tropical regions (Curtis \& Machado 2007). The harvestman D. prospicuus was no exception, and the number of adults, subadults, and juveniles showed clear variations throughout the year (Fig. 3a). However, contrary to other species, in which the peak in the number of adults occurs during spring and summer (e.g. Acosta et al. 1995, Gnaspini 1996, Mestre \& Pinto-da-Rocha 2004), the population dynamics of $D$. prospicuus does not follow a consistent seasonal pattern. In 2013, the peak in the number of adults occurred in late summer (February-March), but the number of adults recorded during this same period in 2014 was very low when compared with the beginning of the winter (July). The lack of clear seasonal fluctuation in the abundance of adults may be related to the unpredictability of wetlands, which are affected by occasional floods. In our study site, floods produced by south to southeastern winds may disturb the habitat, especially the fallen logs used as shelter and oviposition site by individuals of $D$. prospicuus. Floods may also kill some individuals that are unable to disperse to a non-flooded area (Klimeš 2002). Thus, unpredictable floods may induce equally unpredictable variations in population dynamics of $D$. prospicuus living in tidal wetlands. This scenario is very different from seasonal flooding in the Amazon forest, where both population dynamics and reproductive phenology are adjusted to predictable variations in the water levels (Friebe \& Adis 1983).

No seasonal interruption in the reproductive activity of $D$. prospicuus was detected (Fig. 3b). The length of the breeding season in harvestmen is primarily influenced by the number of months with a mean temperature above $5^{\circ} \mathrm{C}$; whereas precipitation has a secondary, but still important effect (Machado et al.2016). In our study site, the mean monthly temperature is always above $5^{\circ} \mathrm{C}$, and precipitation is not markedly seasonal.Thus, both temperature and precipitation (Fig 1). 
Table I. Best models to predict the number of adults, subadults, juveniles, and egg clutches of the harvestman Discocyrtus prospicuus in a tidal freshwater wetland from Argentina.

\begin{tabular}{|c|c|c|c|c|}
\hline Predictor variables & $\mathbf{K}$ & $\mathrm{AICc}$ & $\triangle \mathrm{AICC}$ & w \\
\hline \multicolumn{5}{|c|}{ Number of adults (males and females) } \\
\hline Temperature + Precipitation + Tide level & 6 & 189.7 & 0.00 & 0.241 \\
\hline Temperature + Tide level & 5 & 190.0 & 0.29 & 0.208 \\
\hline Precipitation + Tide level & 5 & 190.2 & 0.56 & 0.182 \\
\hline Tide level & 4 & 190.9 & 1.19 & 0.133 \\
\hline Temperature + Precipitation & 5 & 191.8 & 2.09 & 0.085 \\
\hline Temperature & 4 & 192.5 & 2.78 & 0.060 \\
\hline Precipitation & 4 & 192.6 & 2.90 & 0.057 \\
\hline Null model & 3 & 193.6 & 3.88 & 0.035 \\
\hline \multicolumn{5}{|c|}{ Number of subadults (males and females) } \\
\hline Null model & 3 & 97.7 & 0.00 & 0.382 \\
\hline Precipitation & 4 & 98.8 & 1.06 & 0.225 \\
\hline Temperature & 4 & 99.5 & 1.77 & 0.157 \\
\hline Tide level & 4 & 100.8 & 3.07 & 0.082 \\
\hline Temperature + Precipitation & 5 & 101.2 & 3.44 & 0.068 \\
\hline Precipitation + Tide level & 5 & 102.3 & 4.54 & 0.040 \\
\hline Temperature + Tide level & 5 & 102.6 & 4.84 & 0.034 \\
\hline Temperature + Precipitation + Tide level & 6 & 104.8 & 7.07 & 0.011 \\
\hline \multicolumn{5}{|c|}{ Number of juveniles } \\
\hline Null model & 3 & 114.6 & 0.00 & 0.260 \\
\hline Temperature & 4 & 115.1 & 0.45 & 0.207 \\
\hline Precipitation & 4 & 115.6 & 0.94 & 0.163 \\
\hline Tide level & 4 & 116.3 & 1.66 & 0.113 \\
\hline Temperature + Precipitation & 5 & 116.3 & 1.72 & 0.110 \\
\hline Temperature + Tide level & 5 & 117.5 & 2.85 & 0.063 \\
\hline Precipitation + Tide level & 5 & 117.6 & 3.02 & 0.058 \\
\hline Temperature + Precipitation + Tide level & 6 & 119.2 & 4.57 & 0.027 \\
\hline \multicolumn{5}{|c|}{ Number of egg clutches } \\
\hline Null model & 3 & 77.4 & 0.00 & 0.501 \\
\hline Tide level & 4 & 79.3 & 1.94 & 0.190 \\
\hline Precipitation & 4 & 79.9 & 2.47 & 0.146 \\
\hline Temperature & 4 & 81.2 & 3.86 & 0.073 \\
\hline Precipitation + Tide level & 5 & 82.1 & 4.71 & 0.048 \\
\hline Temperature + Tide level & 5 & 83.6 & 6.22 & 0.022 \\
\hline Temperature + Precipitation & 5 & 84.2 & 6.79 & 0.017 \\
\hline Temperature + Precipitation + Tide level & 6 & 86.8 & 9.44 & 0.004 \\
\hline
\end{tabular}

$\mathbf{K}$ is the number of parameters in the model, AICc is the Akaike's information criterion for small samples, $\triangle \mathrm{AICc}$ is the difference between the AICC value of the model and the best-ranked model, and $w$ is the weight of the model. When model averaged, $95 \%$ confidence intervals overlap with zero for all variables (see Table II). 
Table II. Coefficients of the predictor variables based on model average. The full list of models for each response variable is presented in Table I. When the $95 \%$ confidence interval does not cross zero, the coefficient is highlighted in bold.

\begin{tabular}{|c|c|c|c|c|}
\hline \multirow{2}{*}{ Response variable } & \multicolumn{4}{|c|}{ Coefficient (95\% confidence interval) } \\
\cline { 2 - 5 } & Intercept & Temperature & Precipitation & Tide level \\
\hline \multirow{2}{*}{ Number of adults } & $\mathbf{3 1 . 9 2}$ & 0.53 & -1.03 & -3.84 \\
& $(21.02,42.82)$ & $(-5.49,7.30)$ & $(-4.37,6.44)$ & $(-9.86,2.18)$ \\
\hline \multirow{2}{*}{ Number of subadults } & $\mathbf{3 . 1 2}$ & 0.42 & -0.52 & - \\
\hline \multirow{2}{*}{ Number of juveniles } & $(2.17,4.07)$ & $(-0.32,1.16)$ & $(-1.18,0.13)$ & -0.44 \\
& $\mathbf{5 . 9 3}$ & -0.72 & -0.61 & $(-1.48,0.60)$ \\
\hline \multirow{2}{*}{ Number of egg clutches } & $(3.74,8.12)$ & $(-1.78,0.32)$ & $(-1.54,0.31)$ & -0.32 \\
& $\mathbf{1 . 8 6}$ & - & - & $(-0.77,0.12)$ \\
\hline
\end{tabular}

conditions seem to favor reproductive activity throughout the year. However, in a continental population from Uruguay facing similar climatic conditions (i.e. seasonal variation in temperature and precipitation), the breeding season of $D$. prospicuus is restricted to the wettest and warmest months, from October to March (Toscano-Gadea 2011). Therefore, the interpopulation difference in the length of breeding season cannot be explained by these two abiotic factors. We argue that high soil moisture throughout the year, as occurs in coastal wetlands around the world (Tiner 2018), could explain this difference. Given that harvestman eggs are sensitive to dehydration (Belozerov 2012), high soil moisture may favor no interruption in the reproductive activity of $D$. prospicuus in tidal wetlands. The length of the breeding season is important because it influences the synchrony of female reproduction and the intensity of male-male competition for mates (Emlen \& Oring 1977). At the interspecific level, short breeding seasons in harvestmen are associated with scramble competition polygyny mating system and low sexual dimorphism related to male weaponry (Machado et al. 2016). At the intraspecific level, however, we have limited data on how the type of mating system and the magnitude of sexual dimorphism vary between populations (e.g. Burns \& Tsurusaki 2016). Therefore, D. prospicuus may be a good study species to explore this question.

Although we do not have quantitative data on sexual differences in survival or movement during development for any harvestman species, the data gathered here show that subadult sex ratio was male-biased (Fig. 3c). This finding suggests that male survival during juvenile stages may be higher than female survival or that females tend to disperse to other areas before reaching adulthood. However, the sex ratio was femalebiased after individuals reach adulthood (Fig. $3 d$ ), which contrasts with other species of Laniatores studied (e.g. Ferreira et al. 2009, Gnaspini 1996, Mestre \& Pinto-da-Rocha 2004, Pinto-da-Rocha 1996a,b). Since surrounding areas in the island exhibit a high degree of landscape anthropization (where we never found D. prospicuus individuals) or are depressed areas that accumulate water, the hypothesis of an active dispersion strategy can be rejected. Nevertheless, a passive dispersal could take place since this species can survive 
long-distance raft dispersal during flooding events (Guerrero et al. 2017)

Most harvestmen species belonging to the suborder Laniatores occur in a diversity of habitats where population dynamics seems to be affected mainly by temperature and/ or precipitation (Acosta et al. 1995, Gnaspini 1996, Mestre \& Pinto-da-Rocha 2004). Contrary to this general pattern, none of the studied variables was a strong predictor of individual abundance in this island population. Unpredictable variations in population density due to flooding events may obscure the relationship between abundance fluctuations and abiotic factors. However, given that fluctuations in temperature and soil moisture seems to be small enough to favor harvestmen activity throughout the year, abundance variations could be also driven by biotic rather than by abiotic interactions. Harvestmen predators and/or food availability may play an important role in the regulation of population density (Batzer \& Boix 2016). As in the case of European trogulids, whose distribution reflects the distribution of their prey (Curtis \& Machado 2007), abundance variations of $D$. prospicuus may be reflecting prey abundance fluctuations over the year. The match-mismatch hypothesis postulates that those individuals that best match their phenology with resource phenology have the highest fitness (Cushing 1990). Given that offspring diets vary throughout ontogeny, several prey phenologies must be considered. Fluctuations on ground-dwelling invertebrates, such as small arthropods and earthworms, may decrease or increase food availability to adults and subadults (e.g. Vannier 1983, Kizilkaya et al. 2011). However, given body size constraint, fluctuations in the abundance of micro-arthropods may increase or decrease food supply to juveniles. Harvestman eggs are highly sensitive to fungal infection (Cokendolpher \& Mitov 2007), and fungi also show a well-marked periodicity throughout the year (Gulis et al. 2006). Temporal changes in vegetation and soil properties may increase the availability and diversity of suitable microhabitats for both prey and predators (De Szalay \& Resh 2000). Also, although we focused on monthly variations of the daily highest tide, changes in water-level fluctuations can occur over varying time scales-from hourly to decadal (Cooper \& Uzarski 2016). It has been shown that regular water-mixing action helps to distribute nutrients and other dissolved materials that could affect ground-dwelling invertebrates (Cooper \& Uzarski 2016). For instance, micro-arthropods usually respond to waterlogging performing vertical migrations in the soil (Eisenbeis \& Wichard 2012). Despite their importance for management and conservation issues, the complex ecology of wetland invertebrates is still poorly known (Batzer \& Boix 2016). In line with this, the predators or the preys of D. prospicuus in natural conditions in this area are also unknown.

There is a great amount of ecological information for terrestrial arthropods in several types of environments, but few studies have focused on populations living in tidal freshwater wetlands. Our findings indicate that the population dynamics and reproductive phenology of the harvestman D. prospicuus in a tidal freshwater wetland are markedly different from other harvestman species living in other types of habitats. In forests, grasslands, and even caves, water is a limiting factor, so that abundance, individual activity, and the reproductive period are positively related to rainfall (Curtis \& Machado 2007). In wetlands, constant high moisture coupled with mild temperatures probably allows individuals of 
D. prospicuus to remain active throughout the entire year and to have a more extended breeding season than conspecific populations living in drier habitats in the mainland. In the future, it would be interesting to study populations of $D$. prospicuus living in different habitat types to better understand how local ecological conditions shape interpopulation variations in ecological, behavioral, and lifehistory traits.

\section{Acknowledgments}

We are grateful to G. Machado, C. Komposch, D. Baldo and F. Kolenc for helpful discussions and comment on a previous version of the manuscript. We also thank M. Iglesias, J. Rossi, and H. and M.E. Mora for the hospitality and help during the fieldwork, Sección Mareas from the Servicio de Hidrografía Naval, and A. Gonzalez from Meteorological Station "Delta del Paraná"-INTA for providing the data on tide records, and temperature and precipitation, respectively. M. del Priore, F. Kolenc, and L. Steingard provided valuable literature. PPI and MOP are supported by Consejo Nacional de Investigaciones Científicas y Técnicas (CONICET). We are also grateful to an anonymous reviewer for his/ her constructive comments and suggestions that improved the manuscript.

\section{REFERENCES}

ACOSTA LE \& GUERRERO EL. 2011. Geographical distribution of Discocyrtus prospicuus (Arachnida: Opiliones: Gonyleptidae): Is there a pattern? Zootaxa 3043: 1-24.

ACOSTA LE, PEREYRA FE \& PIZZI RA. 1995. Field observations on Pachyloidellus goliath (Opiliones, Gonyleptidae) in Pampa de Achala, province of Cordoba, Argentina. Bull Br Arachnol Soc 10: 23-28.

ALMEIDA-NETO M, MACHADO G, PINTO DA ROCHA R \& GIARETTA AA. 2006. Harvestman (Arachnida: Opiliones) species distribution along three Neotropical elevational gradients: an alternative rescue effect to explain Rapoport's rule? J Biogeogr 33: 361-375.

ANDERSON JT \& SMITH LM. 2000. Invertebrate response to moist-soil management of playa wetlands. Ecol Appl 10: 550-558.

ANTVOGEL H \& BONN A. 2001. Environmental parameters and microspatial distribution of insects: a case study of carabids in an alluvial forest. Ecography 24: 470-482.
BARTON K. 2015. MuMIn: Multi-Model Inference. R package version 1.15.1. Available from: http://CRAN.R-project.org/ package $=$ MuMIn .

BATZER D \& BOIX D. 2016. Invertebrates in Freshwater Wetlands. Switzerland: Springer.

BELOZEROV V. 2012. Dormant stages and their participation in adjustment and regulation of life cycles of harvestmen (Arachnida, Opiliones). Entomol Rev 92: 688-713.

BOLKER BM. 2008. Ecological models and data in R. Princeton, NJ: Princeton University Press.

BURNHAM KP \& ANDERSON DR. 2003. Model selection and multimodel inference: a practical information-theoretic approach. New York: Springer Science \& Business Media.

BURNS M \& TSURUSAKI N. 2016. Male reproductive morphology across latitudinal clines and under longterm female sex-ratio bias. Integr Comp Biol 56: 715-727.

CANALS J. 1936. Observaciones biológicas en arácnidos del orden Opiliones. Rev Chil Hist Nat 40: 61-63.

CHOWN SL \& NICOLSON S 2004. Insect physiological ecology: mechanisms and patterns. Oxford University Press.

COKENDOLPHER JC \& MITOV PG. 2007. Natural enemies. In: Pinto-da-Rocha R, Machado G \& Giribet G (Eds), Harvestmen: The Biology of Opiliones, Cambridge, MA: Harvard University Press, p. 339-373.

COOPER MJ \& UZARSKI DG. 2016. Invertebrates in great lakes marshes. In: Batzer D \& Boix D (Eds), Invertebrates in Freshwater Wetlands, Switzerland: Springer, p. 287-320.

CURTIS DJ \& MACHADO G. 2007. Ecology. In: Pinto-da-Rocha R, Machado G \& Giribet G (Eds), Harvestmen: the biology of Opiliones, Cambridge: Harvard University Press, $\mathrm{p}$. 280-308.

CUSHING DH. 1990. Plankton production and year-class strength in fish populations: an update of the match/ mismatch hypothesis. Adv Mar Biol 26: 249-293.

DE SZALAY FA \& RESH VH. 2000. Factors influencing macroinvertebrate colonization of seasonal wetlands: responses to emergent plant cover. Freshwater Biol 45: 295-308.

DORMANN CF, ELITH J, BACHER S, BUCHMANN C, CARL G, CARRÉ G, MARQUÉZ JRG, GRUBER B, LAFOURCADE B \& LEITÃO PJ. 2013. Collinearity: a review of methods to deal with it and a simulation study evaluating their performance. Ecography 36: 27-46.

EISENBEIS G \& WICHARD W. 2012. Atlas on the biology of soil arthropods. Berlin: Springer Science \& Business Media. 
EMLEN ST \& ORING LW. 1977. Ecology, sexual selection, and the evolution of mating systems. Science 197: 215-223.

ESPOSITO VINZI V, CHIN WW, HENSELER J \& WANG H. 2010. Handbook of partial least squares: Concepts, methods and applications.

FERREIRA RL, KAWAMURA EM, PONTES GB, ALMEIDA SSP, ARAÚJO VA \& TEIXEIRA VRC. 2009. Ecologia populacional de Goniosoma sp. (Arachnida, Opiliones, Gonyleptidae) em uma caverna ferruginosa do município de Ouro Preto, MG. Rev Bras Zoociênc 7: 203-216.

FOX J, FRIENDLY GG, GRAVES S, HEIBERGER R, MONETTE G, NILSSON H, RIPLEY B, WEISBERG S, FOX MJ \& SUGGESTS M. 2007. The car package. R Foundation for Statistical Computing.

FRIEBE B \& ADIS J. 1983. Entwicklungszyklen von Opiliones (Arachnida) im Schwarzwasser.-Überschwemmungswald (Igapó) des Rio Tarumã Mirim (Zentralamazonien, Brasilien). Amazoniana 8: 101-110.

GNASPINI P. 1996. Population ecology of Goniosoma spelaeum, a cavernicolous harvestman from southeastern Brazil (Arachnida: Opiliones: Gonyleptidae). J Zool 239: 417-435.

GUERRERO EL ET AL. 2017. Inventario de la fauna transportada por balsas de vegetación flotante en el Sistema fluvial del Río de La Plata. Rev Mus Argentino Cienc Nat 19: 177-183.

GULIS V, KUEHN K \& SUBERKROPP K. 2006. The role of fungi in carbon and nitrogen cycles in freshwater ecosystems. In: Gadd GM (Ed), Fungi in biogeochemical cycles, Cambridge, UK: Cambridge University Press, p. 404-435.

HILLYARD PD \& SANKEY JH. 1989. Harvestmen: keys and notes for the identification of the species. n. 4: Brill Archive.

Holmberg E. 1876. Arácnidos argentinos. An Agr Rep Argentina 4: 1-30.

KANDUS P \& MALVÁREZ AI. 2004. Vegetation patterns and change analysis in the lower delta islands of the Paraná River (Argentina). Wetlands 24: 620-632.

KANDUS P, QUINTANA RD \& BÓ RF. 2006. Patrones de paisaje y biodiversidad del Bajo Delta del Río Paraná. Pablo Casamajor Ediciones, Buenos Aires.

KIZILKAYA R, KARACA A, TURGAY OC \& CETIN SC. 2011. Earthworm interactions with soil enzymes. In: Karaca A (Ed), Biology of earthworms, NY: Springer, p. 141-158.

KLIMEŠ L. 2002. Effect of floods on ground beetles (Carabidae) and harvestmen (Opiliones). In: Květ J, Jeník J and Soukupová L (Eds), Freshwater wetlands and their sustainable future A case study of the Trebon
Basin Biosphere Reserve, Czech Republic Man and the Biospere Series 28, New York: UNESCO \& Parthenon Publishing Group, p. 361-372.

MACHADO G, BUZATTO BA, GARCÍA-HERNÁNDEZ S \& MACÍASORDÓÑEZ R. 2016. Macroecology of sexual selection: a predictive conceptual framework for large-scale variation in reproductive traits. Am Nat 188: S8-S27.

MESTRE LAM \& PINTO-DA-ROCHA R. 2004. Population dynamics of an isolated population of the harvestman Ilhaia cuspidata (Opiliones, Gonyleptidae), in Araucaria Forest (Curitiba, Paraná, Brazil). J Arachnol 32: 208-220.

PEEL MC, FINLAYSON BL \& MCMAHON TA. 2007. Updated world map of the Köppen-Geiger climate classification. Hydrol Earth Syst Sci Discuss 4: 439-473.

PINHEIRO J, BATES D, DEBROY S \& SARKAR D. 2014. nlme: linear and nonlinear mixed effects models. R package version 3.1-117. Available at http://CRAN.R-project.org/ package $=$ nlme.

PINTO-DA-ROCHA R. 1996a. Biological notes on and population size of Pachylospeleus strinatii Silhavy, 1974 in the Gruta das Areias de Cima, Iporanga, south-eastern Brazil (Arachnida, Opiliones, Gonyleptidae). Bull Br Arachnol Soc 10: 189-192.

PINTO-DA-ROCHA R. 1996b. Description of the male of Daguerreia inermis Soares \& Soares, with biological notes on population size in the Gruta da Lancinha, Paraná, Brazil (Arachnida, Opiliones, Gonyleptidae). Rev Bras Zool 13: 833-842.

R CORE TEAM. 2015. R: a language and environment for statistical computing. R Foundation for Statistical Computing, Vienna. http://www.r-project.org/.

RINGUELET RA. 1959. Los arácnidos argentinos del Orden Opiliones. Rev Mus Argent Cienc Nat 5: 128-439.

RIVRUD IM, LOE LE \& MYSTERUD A. 2010. How does local weather predict red deer home range size at different temporal scales? J An Ecol 79: 1280-1295.

SANTOS FH . 2007. Ecophysiology. In: Pinto-Da-Rocha R, Machado G \& Giribet G (Eds), Harvestmen: the biology of Opiliones, Cambridge: Harvard University Press, p. 473-488.

SCHIELZETH H. 2010. Simple means to improve the interpretability of regression coefficients. Methods Ecol Evol 1: 103-113.

STANLEY E. 2011. Egg hiding in four harvestman species from Uruguay (Opiliones: Gonyleptidae). J Arachnol 39: 495-496. 
SYMONDS MR \& MOUSSALLI A. 2011. A brief guide to model selection, multimodel inference and model averaging in behavioural ecology using Akaike's information criterion. Behav Ecol Sociobiol 65: 13-21.

TINER RW. 2018. Hydrology of coastal wetlands. In: Finlayson CM, Everard M, Irvine K, Mcinnes RJ, Middleton BA, Van Dam AA \& Davidson NC (Eds), The wetland book I: Structure and function, management and methods, Netherlands: Springer, p. 1-14.

TOSCANO-GADEA CA. 2011. Opiliones en Uruguay. In: Aisenberg A, Toscano-Gadea C \& Ghione S (Eds), Guía de Aracnidos del Uruguay, Montevideo: Ediciones de la Fuga, p. 212-221.

VANNIER G. 1983. The importance of ecophysiology for both biotic and abiotic studies of the soil. In: Finlayson CM, Everard M, Irvine K, Mcinnes RJ, Middleton BA, Van Dam AA \& Davidson NC (Eds), The wetland book I: Structure and function, management and methods Louvain-la-Neuve: Université Catholique de Louvain, p. 289-314.

VERHOEF HA. 1977. Soil moisture and the population dynamics of coexisting Collembola. Ecol Bull 25: 480-482.

ZUUR AF, IENO EN, WALKER NJ, SAVELIEV AA \& SMITH GM 2009. GLM and GAM for count data. Mixed effects models and extensions in ecology with R: Springer, p. 209-243.

\section{How to cite}

IGLESIAS PP \& PEREYRA MO. 2020. Population dynamics and reproductive phenology of a harvestman in a tidal freshwater wetland. An Acad Bras Cienc 92: e20181123. DOI 10.1590/0001-3765202020181123.

Manuscript received on October 25, 2018;

accepted for publication on March 13, 2019

\section{PATRICIA P. IGLESIAS}

https://orcid.org/0000-0002-3979-4253

\section{MARTÍN O. PEREYRA ${ }^{2}$}

https://orcid.org/0000-0002-1998-0163

'División Aracnología, Museo Argentino de Ciencias Naturales "Bernardino Rivadavia” - CONICET, Av. Ángel Gallardo, 470, C1405DJR Buenos Aires, Argentina

${ }^{2}$ División Herpetología, Museo Argentino de Ciencias Naturales "Bernardino Rivadavia” - CONICET, Av. Ángel Gallardo, 470, C1405DJR Buenos Aires, Argentina

Correspondence to: Patricia Paola Iglesias

E-mail:patricia.p.iglesias@gmail.com

\section{Author Contributions}

P.P.I. and M.O.P conceived of the study and carried out the fieldwork. P.P.I. performed the analyses and wrote the original draft of the manuscript. M.O.P. provided critical comments on the manuscript. All authors approved the final version of the manuscript for submission.

\section{(cc) BY}

